

\title{
A chromatographic procedure for semi-quantitative evaluation of caseinphosphopeptides in cheese
}

Coralie Dupas, Isabelle Adt, Amandine Cottaz, Rachel Boutrou, Daniel Molle, Julien Jardin, Thierry Jouvet, Pascal Degraeve

\section{To cite this version:}

Coralie Dupas, Isabelle Adt, Amandine Cottaz, Rachel Boutrou, Daniel Molle, et al.. A chromatographic procedure for semi-quantitative evaluation of caseinphosphopeptides in cheese. Dairy Science \& Technology, 2009, 89 (6), pp.519-529. 10.1051/dst/2009027 . hal-00895716

\section{HAL Id: hal-00895716 https://hal.science/hal-00895716}

Submitted on 1 Jan 2009

HAL is a multi-disciplinary open access archive for the deposit and dissemination of scientific research documents, whether they are published or not. The documents may come from teaching and research institutions in France or abroad, or from public or private research centers.
L'archive ouverte pluridisciplinaire HAL, est destinée au dépôt et à la diffusion de documents scientifiques de niveau recherche, publiés ou non, émanant des établissements d'enseignement et de recherche français ou étrangers, des laboratoires publics ou privés. 


\title{
A chromatographic procedure for semi-quantitative evaluation of caseinphosphopeptides in cheese
}

\author{
Coralie Dupas ${ }^{1}$, Isabelle Adt ${ }^{1}$, Amandine CotTAz ${ }^{1}$, Rachel Boutrou ${ }^{2}$ \\ Daniel Molle $^{2}$, Julien Jardin ${ }^{2}$, Thierry Jouvet ${ }^{3}$, Pascal Degraeve ${ }^{1 *}$ \\ ${ }^{1}$ Université de Lyon, Université Lyon 1, Laboratoire de Recherche en Génie Industriel Alimentaire, \\ EA 3733, Département de Génie Biologique IUT A, Technopole Alimentec, rue Henri de Boissieu, \\ 01060 Bourg-en-Bresse cedex 9, France \\ ${ }^{2}$ INRA Agrocampus Ouest, UMR1253, Science et Technologie du Lait et de l'Euf, \\ 35042 Rennes, France \\ ${ }^{3}$ Actilait/ITFF Institut Technique du Lait et des Produits Laitiers, Technopole Alimentec, \\ rue Henri de Boissieu, 01060 Bourg-en-Bresse cedex 9, France
}

Received 1st February 2009 - Revised 19 May 2009 - Accepted 9 June 2009

Published online 4 August 2009

\begin{abstract}
Caseinphosphopeptides (CPPs) are phosphorylated fragments of caseins, which are found in dairy products. One of their unique features is their ability to bind calcium. There are several published methods to extract CPPs from cheese, but none allows their quantitative evaluation. A chromatographic procedure allowing a semi-quantitative evaluation of cheese CPPs was adapted from a previously published method and tested on Beaufort cheese. Water-soluble peptides were extracted from cheese and purified using cation-exchange chromatography followed by immobilised metal-ion affinity chromatography (IMAC). CPPs were identified using mass spectrometry (LC-ESI-MS/MS). Fifty-five peptides, including $48 \mathrm{CPPs}$ carrying one to three phosphorylations, were identified in Beaufort cheese. It can thus be considered that the selectivity of the chromatographic procedure proposed is sufficient for a semi-quantification of CPPs with a molecular mass ranging from 600 to $10000 \mathrm{~g} \cdot \mathrm{mol}^{-1}$ in cheese. As IMAC fractions contain molecules with a molecular mass $<600 \mathrm{~g} \cdot \mathrm{mol}^{-1}$ (such as phosphoserine), a gel filtration step was performed in order to remove these compounds. The semi-quantification based on an estimation of the extinction molar coefficient of CPPs at $215 \mathrm{~nm}$ allowed to estimate that the CPPs content of the fresh Beaufort cheese sample analysed was around $1.9 \mathrm{~g} \cdot 100 \mathrm{~g}^{-1}$.
\end{abstract}

caseinphosphopeptide / cheese / liquid chromatography / mass spectrometry

摘要 - 色谱法半定量测定干酪中酪蛋白磷酸肽。酪蛋白磷酸肽 (CPPs) 是乳品生产过程 中形成的酪蛋白的磷酸化碎片, 其最重要的特性是具有结合钻的能力。关于从干酪中提取 CPPs 的报道较多，但从未有人介绍定量评价 CPPs 的方法。一种色谱方法可以半定量的 测定干酪中 CPPs 含量, 测定结果与前人报道的测定 Beaufort 干酪中 CPPs 测定结果一致。 从干酪中提取出水溶性多肽, 然后用阳离子交换色谱纯化, 接着用固定化金属离子亲和色 谱纯化 (IMAC), 最后用质谱法 (LC-ESI-MS/MS) 鉴定 CPPs。从 Beaufort 干酪中鉴 定出 55 多肽, 包括带有 1-3 个磷酸化基团的 48 种酪蛋白磷酸肽。色谱法可以有效地 对对干酪中分子量在 $600 \sim 10000 \mathrm{~g} \cdot \mathrm{mol}^{-1}$ 的 CPPs 进行半定量分析。由于亲和色谱纯化

*Corresponding author (通讯作者): pascal.degraeve@iut.univ-lyon1.fr 
的馏分中含有分子量小于 $600 \mathrm{~g} \cdot \mathrm{mol}^{-1}$ 的分子 (如磷酸丝氨酸), 凝胶过滤步骤就是为了除 去这些小分子化合物。根据估计 CPPs 在 $215 \mathrm{~nm}$ 的摩尔消光系数可以半定量地估算出新 鲜干酪中 CCPs 的含量约为 $1.9 \mathrm{~g} \cdot 100 \mathrm{~g}^{-1}$ 。

\section{酪蛋白磷酸肽 / 干酪 / 液相色谱 / 质谱}

Résumé - Méthode d'évaluation semi-quantitative des caséinophosphopeptides dans le fromage. Les caséinophosphopeptides (CPP) sont des fragments phosphorylés de caséine présents dans les produits laitiers qui possèdent la capacité de se lier au calcium. S'il existe différentes méthodes pour les extraire à partir de fromage, aucune ne permet cependant leur évaluation quantitative. La méthode proposée ici pour l'évaluation semi-quantitative des CPPs a été adaptée à partir de travaux publiés précédemment par une autre équipe ; elle a été appliquée au Beaufort. Après extraction des peptides hydrosolubles du fromage, les CPPs ont été purifiés par une chromatographie d'échange de cations suivie d'une chromatographie d'affinité pour les ions métalliques immobilisés (IMAC). Les CPPs ont ensuite été identifiés par spectrométrie de masse (LC-ESIMS/MS). Cinquante-cinq peptides, dont 48 CPPs portant de 1 à 3 phosphorylations, ont ainsi pu être identifiés dans le Beaufort. On peut donc considérer que la sélectivité de la procédure chromatographique proposée est suffisante pour une évaluation semi-quantitative des CPPs. Une étape de filtration sur gel a ensuite permis de séparer les molécules éluées après l'IMAC présentant une masse moléculaire inférieure à $600 \mathrm{~g} \cdot \mathrm{mol}^{-1}$, comme la phosphosérine. La teneur en CPPs, définis comme des composés phosphorylés présentant une masse moléculaire comprise entre 600 et $10000 \mathrm{~g} \cdot \mathrm{mol}^{-1}$, de l'échantillon de Beaufort considéré, a ainsi pu être estimée à $1,9 \mathrm{~g}$ pour $100 \mathrm{~g}$ en se basant sur une estimation de leur coefficient d'extinction moléculaire à $215 \mathrm{~nm}$.

\section{caséinophosphopeptide / fromage / chromatographie liquide / spectrométrie de masse}

\section{INTRODUCTION}

Milk and dairy products are the most important dietary sources of calcium in western countries. Indeed, the dairy products' calcium bioavailability is better than that of the other sources, such as vegetables [7]. This could partly be due to their contents in highly phosphorylated fragments of caseins, named caseinphosphopeptides (CPPs). These peptides appear mainly during the elaboration of milk products such as cheese or yoghurt, under the action on caseins of milk-endogenous, milk-clotting and/or microbial enzymes. They may also arise from $\alpha_{\mathrm{S}^{-}}, \alpha_{\mathrm{S} 2^{-}}$and $\beta$-casein digestion in the gut [7]. One unique feature of CPPs is their ability to form CPP-metal ion complexes, which would potentially increase the bioavailability of calcium and iron, notably by maintaining metals in a soluble form in the distal small intestine [18]. As a consequence, CPPs dietary supplementation could be interesting for calcium-uptake deficient populations, or in bone-loss prevention for particular populations, such as postmenopausal women [23]. However, the enhancement of calcium absorption in the gut by CPPs is still questioned [10]. Moreover, it has been shown that CPPs possess unique anticariogenic properties [3, 17]. Milk-derived products containing CPPs have already been commercialised with health claims (casein hydrolysate CE90CPP, DMV International, Veghel, The Netherlands). However, quite little is known concerning the CPPs contents of traditional dairy products, such as cheese. CPPs have been identified in casein hydrolysates, milk-based infant formula [1, 16] and fermented dairy products such as yogurt $[4,12]$ and cheese $[2,8,12,14,21]$. Two approaches were used: either systematic identification of all peptides liberated as a result of the enzymatic caseinolysis in dairy products, or selective identification, involving a purification procedure allowing their selective isolation. In both approaches, identification was carried out using LC-ESIMS/MS and/or sequencing by Edman 
degradation. Selective precipitation using ethanol combined with a calcium chloride addition is a convenient procedure to isolate CPPs [19]. More recently, Hynek et al. [11] and Lund and Ardö [14] introduced immobilised metal-ion affinity chromatography (IMAC) to recover CPPs from cheese water-soluble extracts (WSEs). The chromatographic procedure proposed by Lund and Ardö [14] included a cation-exchange chromatography step (with a strong cation exchanger), prior to the IMAC step, in order to remove the peptides present in cheese extracts, which could bind to the IMAC support, although they are not phosphorylated. The multi-step linear gradient of phosphate that was used to elute progressively CCPs from the $\mathrm{Fe}^{3+}$-IMAC support allowed the successive elution of mono-, di- and polyphosphorylated CPPs that were then identified by LC-ESI-MS/MS.

However, after the pioneering preliminary results of Hynek et al. [11], this chromatographic procedure was never used to quantify CPPs in dairy products. The aim of this study was to assess the validity of the chromatographic procedure for the semi-quantitative evaluation of their CPPs contents. This assessment was carried out on Beaufort cheese, a traditional Swiss-type cheese. It was considered a potent source of CPPs, due to its high casein contents, associated with its long ripening period (at least five months).

\section{MATERIALS AND METHODS}

\subsection{Materials}

Six-month-old Beaufort cheese was provided by the French Technical Institute for Milk and Dairy Products (Actilait - Bourgen-Bresse, France). All chemicals were of analytical grade and Milli-Q water (Millipore, Bedford, MA, USA) was used throughout the study.

\subsection{Preparation of cheese WSE}

Grated Beaufort cheese (20 g) was homogenised in $40 \mathrm{~mL}$ of water for $10 \mathrm{~min}$ at room temperature at $20500 \mathrm{rpm}$ using an IKA Ultra-Turrax T 25 system (Janke \& Kunkel, Staufen, Germany). A WSE was prepared from this mixture as described by Kuchroo and Fox [13], with slight modifications. The homogenate was first held under gentle stirring for $1 \mathrm{~h}$ at $40{ }^{\circ} \mathrm{C}$, and then centrifuged at $10000 \times \mathrm{g}$ for $30 \mathrm{~min}$ at $4{ }^{\circ} \mathrm{C}$, which formed a pellet of insoluble material. The WSE was recovered through the upper cheese fat layer using a Pasteur pipette. It was then filtered through a glass membrane and through a $0.45 \mu \mathrm{m}$ cellulose Celtron syringe filter (Schleicher \& Schuell, Versailles, France). Thereafter, molecules with a molecular mass exceeding $10000 \mathrm{~g} \cdot \mathrm{mol}^{-1}$ (which cannot be considered as peptides) were removed by ultrafiltration through polyethersulphone membranes (cut-off $=10 \mathrm{~kg} \cdot \mathrm{mol}^{-1}$, Millipore, SaintQuentin-en-Yvelines, France). Ultrafiltered cheese WSE containing CPPs (i.e. the $<10000 \mathrm{~g} \cdot \mathrm{mol}^{-1}$ fraction) was kept at $-20{ }^{\circ} \mathrm{C}$ until further analysis.

\subsection{Isolation of phosphopeptides}

Phosphopeptides were isolated from cheese WSE by cation-exchange chromatography followed by $\mathrm{Fe}$ (III) metal affinity chromatography, following the procedure described by Lund and Ardö [14], with slight modifications. The samples were first diluted by one-fifth in $10 \mathrm{mmol} \cdot \mathrm{L}^{-1} \mathrm{HEPES}$ buffer, final volume $15 \mathrm{~mL}$, and the $\mathrm{pH}$ was adjusted to 7.0 using $30 \%(\mathrm{~m} / \mathrm{v}) \mathrm{NaOH}$. The diluted and $\mathrm{pH}$-adjusted extract was then loaded onto a strong cation exchanger column (Macro-Prep High S support, Bio-Rad Laboratories, Marnes-la-Coquette, France, $15 \mathrm{~mL}$ bed volume) equilibrated with $10 \mathrm{mmol} \cdot \mathrm{L}^{-1}$ HEPES buffer, $\mathrm{pH}$ 7.0. The flow rate was $15 \mathrm{~mL} \cdot \mathrm{h}^{-1}$. After $4 \mathrm{~h}$ 




Figure 1. Chromatogram of Beaufort cheese WSE on the IMAC column, and separation into fractions according to Lund and Ardö [14]. The column was eluted with a gradient of 0 to $0.2 \mathrm{~mol} \cdot \mathrm{L}^{-1}$ ammonium dihydrogen phosphate $\mathrm{pH} 4.4$. Detection was performed at $215 \mathrm{~nm}$. Total loaded samples correspond to $1.5 \mathrm{~g}$ Beaufort cheese.

flow-through with $60 \mathrm{~mL}$ HEPES buffer, the column was eluted with a $5 \mathrm{~h}$ linear gradient of $0-1 \mathrm{~mol} \cdot \mathrm{L}^{-1} \mathrm{NaCl}$ in HEPES buffer. The first $60 \mathrm{~mL}$ was collected and further purified by IMAC-Fe(III) using a $15 \mathrm{~mL}$ IDA-Sepharose fast flow gel column from Amersham Biosciences (Uppsala, Sweden). The column was equilibrated with two column volumes of $0.1 \mathrm{~mol} \cdot \mathrm{L}^{-1} \mathrm{FeCl}_{3}$, washed with $0.1 \mathrm{~mol} \cdot \mathrm{L}^{-1}$ sodium acetate, $\mathrm{pH} 3.0$, and then loaded with the collected flow-through from the cation-exchange chromatography $(60 \mathrm{~mL})$ (after its $\mathrm{pH}$ was adjusted to 3.0 using $\left.1 \mathrm{~mol} \cdot \mathrm{L}^{-1} \mathrm{HCl}\right)$. After washing for $1 \mathrm{~h}$ with sodium acetate buffer, the substances were eluted from the column with a three-step linear gradient, from $0 \%$ to $100 \% 0.2 \mathrm{~mol} \cdot \mathrm{L}^{-1}$ ammonium dihydrogen phosphate, $\mathrm{pH} 4.4$, in $0.1 \mathrm{~mol} \cdot \mathrm{L}^{-1}$ sodium acetate, $\mathrm{pH} 3.0$ (Fig. 1). The flow rate was $120 \mathrm{~mL} \cdot \mathrm{h}^{-1}$. According to Lund and Ardö
[14], the affinity of CPPs for the Fe(III) column is proportional to their phosphorylation degree, when such a gradient is applied. Fractions were collected and gathered into five main pools corresponding to these different degrees. Monophosphorylated CPPs would be eluted from $0 \%$ to $10 \%$ $\mathrm{NH}_{4} \mathrm{H}_{2} \mathrm{PO}_{4}\left(0-0.02 \mathrm{~mol} \cdot \mathrm{L}^{-1}\right.$, from 4.5 to $18 \mathrm{~min}$ elution: fraction $\mathrm{I}$; from 18 to 33 min elution: fraction II), diphosphorylated from $10 \%$ to $50 \% \mathrm{NH}_{4} \mathrm{H}_{2} \mathrm{PO}_{4}(0.02-$ $0.1 \mathrm{~mol} \cdot \mathrm{L}^{-1}$, from 33 to $54 \mathrm{~min}$ elution: fraction III), while polyphosphorylated CPPs would appear from $50 \%$ to $100 \%$ (0.1-0.2 $\mathrm{mol} \cdot \mathrm{L}^{-1} \mathrm{NH}_{4} \mathrm{H}_{2} \mathrm{PO}_{4}$, from 54 to 66 min elution: fraction IV and from 66 to 103.5 min elution: fraction V). Areas under the curves (AUCs) (plot of $215 \mathrm{~nm}$ absorbance vs. elution time) were calculated for each fraction. Beaufort WSE purification was performed in triplicate. 


\subsection{Identification of peptides by LC-ESI-MS/MS}

Peptides contained in fractions III-V of the cheese homogenate IMAC-Fe(III) eluate were identified by reverse-phase nanoHPLC-MS/MS. Five millilitres of each sample were dialysed against water to remove salts (100 Da c.o., SpectraPor, Spectrum Laboratories Inc., USA), lyophilised and diluted into $200 \mu \mathrm{L}$ of $0.1 \%$ trifluoroacetic acid (TFA); $6.4 \mu \mathrm{L}$ were then injected (pick-up method). Samples were first concentrated using an RP-HPLC C18 PepMap 100 cartridge, $5 \mu \mathrm{m}, 100 \AA$ $(300 \mu \mathrm{m}$ i.d. $\times 5 \mathrm{~mm})$, then eluted with a gradient, using a flow rate of $200 \mathrm{~nL} \cdot \mathrm{min}^{-1}$, on a PepMap C18 column, $3 \mu \mathrm{m}, 100 \AA$ (75 $\mu \mathrm{m}$ i.d. $\times 150 \mathrm{~mm})$. Buffer A was $2 \%$ acetonitrile $/ 0.08 \%$ formic acid $/ 0.01 \%$ TFA in water, and buffer B 95\% acetonitrile/ $0.08 \%$ formic acid $/ 0.01 \%$ TFA in water [9]. The column was flushed with $90 \%$ buffer A for $5 \mathrm{~min}$ before a $75 \mathrm{~min}$ linear gradient from $10 \%$ to $50 \%$ B was applied. $\mathrm{B}$ proportions were then: $50-70 \%$ in $2 \mathrm{~min}$, then $70 \% \mathrm{~B}$ for $8 \mathrm{~min}, 70-3 \% \mathrm{~B}$ in $2 \mathrm{~min}, 3 \% \mathrm{~B}$ for $6 \mathrm{~min}$ and finally $3-10 \% \mathrm{~B}$ in $2 \mathrm{~min}$, followed by $10 \% \mathrm{~B}$ for $15 \mathrm{~min}$. The nano-HPLC column eluent was directly coupled to a "Q STARXL MS/ MS System" quadrupole orthogonal TOF mass spectrometer, equipped with a ProXeon nanospray ion source (ProXeon Biosystems, Odense, Denmark). LC-ESIMS/MS mass spectra $(1+, 2+, 3+$ charged $)$ were acquired using an IDA (intelligent data acquisition) system (survey scan). Peptides were identified using a home-made database dealing with major milk proteins.

\subsection{Fraction analysis by gel filtration chromatography}

Fractions obtained from IMAC were further analysed by gel filtration chromatography (GFC). Twenty millilitres of each fraction were lyophilised, and resuspended in $2 \mathrm{~mL}$ water, filtered onto $0.45 \mu \mathrm{m}$ cutoff syringe filters and used for analysis. A Perkin Elmer (Norwalk, CT, USA) HPLC system consisting of a binary LC250 pump, a $235 \mathrm{C}$ diode array detector, a computer with TotalChrom Navigator $\left.{ }^{(}\right)$software and a Superdex ${ }^{\circledR}$ Peptide PE 7.5/300 column (Pharmacia Biotech, Uppsala, Sweden) were used. Samples $(100 \mu \mathrm{L})$ were loaded onto the column and eluted for $120 \mathrm{~min}$ with $30 \%$ of $0.1 \%$ TFA in acetonitrile and $70 \%$ of $0.1 \%$ TFA in water. The flow rate was $0.25 \mathrm{~mL} \cdot \mathrm{min}^{-1}$, and detection was carried out at $215 \mathrm{~nm}$.

\section{RESULTS AND DISCUSSION}

\subsection{IMAC-Fe(III) analysis}

In order to determine cheese CPPs contents, a two-step purification strategy, based on the high affinity of phosphate groups to immobilised $\mathrm{Fe}$ (III), was used to isolate phosphopeptides from Beaufort WSEs, according to Lund and Ardö [14], with slight modifications. First, a separation on a cation-exchange column was performed to remove peptides present in the cheese sample, which may also bind to the IMAC-Fe(III) column by coordination interactions between transition metal ions and electron-donating groups of peptides, particularly amino acid residues such as histidine, tryptophan and cystein. Since such peptides were shown by Lund and Ardö [14] to be histidine-rich basic fragments of caseins with a isoelectric point (pI) of 9-11, while most parts of phosphopeptides have pI values below 5, performing cation-exchange chromatography at a $\mathrm{pH}$ of 7 allowed to eliminate most of them prior to IMAC. The second step, IMAC separation on a $\mathrm{Fe}$ (III) column, had to be performed at a $\mathrm{pH}$ of 3 , to prevent the binding of peptides that are rich in carboxylic acids to the $\mathrm{Fe}(\mathrm{III})$ column. The chromatographic procedure was repeated thrice and the relative 
Table I. Identified CPPs for the Beaufort cheese using nano-RP-LC-ESI-MS/MS. Phosphorylated serines are figured using the letter "U", while "U*" stands for phosphorylated threonin. "S. and "T" figure dephosphorylated residues.

\begin{tabular}{|c|c|c|c|}
\hline $\begin{array}{l}\text { Observed } \\
\text { mass }\end{array}$ & $\begin{array}{c}\text { Calculated } \\
\text { mass }\end{array}$ & Sequence & $\begin{array}{c}\text { Sequence assignment } \\
\text { of the peptide }\end{array}$ \\
\hline \multicolumn{4}{|l|}{ Fraction III } \\
\hline 1033.4927 & 1033.3406 & UUEEIVPN & $\alpha_{\mathrm{S} 1} \mathrm{f}(67-74) 2 \mathrm{P}$ \\
\hline 1047.4719 & 1047.4750 & UVEQKHIQ & $\alpha_{\mathrm{S} 1} \mathrm{f}(75-83) 1 \mathrm{P}$ \\
\hline 1793.8827 & 1793.8964 & KYKVPQLEIVPNUAE & $\alpha_{\mathrm{S} 1} \mathrm{f}(103-117) 1 \mathrm{P}$ \\
\hline 2201.0648 & 2201.0881 & YKVPQLEIVPNUAEERLH & $\alpha_{\mathrm{S} 1} \mathrm{f}(104-121) 1 \mathrm{P}$ \\
\hline 1909.9292 & 1909.9299 & VPQLEIVPNUAEERLH & $\alpha_{\mathrm{S} 1} \mathrm{f}(106-121) 1 \mathrm{P}$ \\
\hline 2256.0732 & 2256.0973 & VPQLEIVPNUAEERLHSMK & $\alpha_{\mathrm{S} 1} \mathrm{f}(106-124) 1 \mathrm{P}$ \\
\hline 1585.7344 & 1585.7501 & LEIVPNUAEERLH & $\alpha_{\mathrm{S} 1} \mathrm{f}(109-121) 1 \mathrm{P}$ \\
\hline 1343.6166 & 1343.6234 & IVPNUAEERLH & $\alpha_{\mathrm{S} 1} \mathrm{f}(111-121) 1 \mathrm{P}$ \\
\hline 1689.7743 & 1689.7909 & IVPNUAEERLHSMK & $\alpha_{\mathrm{S} 1} \mathrm{f}(111-124) 1 \mathrm{P}$ \\
\hline 1230.5384 & 1230.5394 & VPNUAEERLH & $\alpha_{\mathrm{S} 1} \mathrm{f}(112-121) 1 \mathrm{P}$ \\
\hline 1034.4075 & 1034.4182 & NUAEERLH & $\alpha_{\mathrm{S} 1} \mathrm{f}(114-120) 1 \mathrm{P}$ \\
\hline 1593.6856 & 1593.6997 & KTVDMEUTEVFTK & $\alpha_{\mathrm{S} 2} \mathrm{f}(137-149) 1 \mathrm{P}$ \\
\hline 1721.7792 & 1721.7947 & KTVDMEUTEVFTKK & $\alpha_{\mathrm{S} 2} \mathrm{f}(137-150) 1 \mathrm{P}$ \\
\hline 1737.7706 & 1737.7896 & KTVDMEUTEVFTKK & $\alpha_{\mathrm{S} 2} \mathrm{f}(137-151) 1 \mathrm{P}$ \\
\hline 1609.6838 & 1609.6947 & TVDMEUTEVFTKK & $\alpha_{\mathrm{S} 2} \mathrm{f}(138-150) 1 \mathrm{P}$ \\
\hline 1294.5454 & 1294.5516 & MEUTEVFTKK & $\alpha_{\mathrm{S} 2} \mathrm{f}(141-150) 1 \mathrm{P}$ \\
\hline 1018.4710 & 1018.4736 & UTEVFTKK & $\alpha_{\mathrm{S} 2} \mathrm{f}(143-150) 1 \mathrm{P}$ \\
\hline 639.2835 & 639.2880 & IVEUL & $\beta \mathrm{f}(12-16) 1 \mathrm{P}$ \\
\hline 1354.4940 & 1354.5054 & $\underline{\text { SLSSUUEESITR }}$ & $\beta \mathrm{f}(15-25) 2 \mathrm{P}$ \\
\hline 1267.4706 & 1267.4734 & $\overline{\mathrm{L}} \underline{\mathbf{S}} \overline{\mathbf{U} U E E S I T R}$ & $\beta \mathrm{f}(16-25) 2 \mathrm{P}$ \\
\hline 1494.5882 & 1494.6004 & L' $\underline{\overline{\mathbf{S}} U U \text { UEESITRIN }}$ & $\beta \mathrm{f}(16-27) 2 \mathrm{P}$ \\
\hline 1381.5144 & 1381.5163 & șÜUEESITRIN & $\beta \mathrm{f}(17-27) 2 \mathrm{P}$ \\
\hline 1381.5144 & 1381.5163 & $\underline{\mathbf{S}}$ USEESITRIN & $\beta \mathrm{f}(17-27) 1 \mathrm{P}$ \\
\hline 1216.5292 & 1216.5376 & KIEKFQUEE & $\beta \mathrm{f}(29-37) 1 \mathrm{P}$ \\
\hline 1472.6651 & 1472.6548 & KIEKFQUEEQQ & $\beta \mathrm{f}(29-39) 1 \mathrm{P}$ \\
\hline 1830.7861 & 1830.8037 & KIEKFQUEEQQQTE & $\beta \mathrm{f}(29-42) 1 \mathrm{P}$ \\
\hline 1945.8234 & 1945.8306 & KIEKFQUEEQQQTED & $\beta \mathrm{f}(29-43) 1 \mathrm{P}$ \\
\hline 2315.9993 & 2316.0158 & KIEKFQUEEQQQTEDELQ & $\beta \mathrm{f}(29-46) 1 \mathrm{P}$ \\
\hline 2559.1138 & 2559.1377 & KIEKFQUEEQQQTEDELQDK & $\beta \mathrm{f}(29-48) 1 \mathrm{P}$ \\
\hline 2431.0219 & 2431.0791 & IEKFQUEKQQQTEDELQDK & $\beta \mathrm{f}(30-48) 1 \mathrm{P}$ \\
\hline 2925.3100 & 2925.3069 & IEKFQUEEQQQTEDELQDKIHPF & $\beta \mathrm{f}(30-52) 1 \mathrm{P}$ \\
\hline 3353.4756 & 3353.5089 & IEKFQUEEQQQTEDELQDKIHPFAQTQ & $\beta \mathrm{f}(30-56) 1 \mathrm{P}$ \\
\hline 1575.5980 & 1575.6454 & KFQUEKQQQTED & $\beta \mathrm{f}(32-43) 1 \mathrm{P}$ \\
\hline 2060.8005 & 2060.8212 & KFQUEEQQQTEDELQD & $\beta \mathrm{f}(32-47) 1 \mathrm{P}$ \\
\hline 2683.1587 & 2683.1803 & KFQUEEQQQTEDELQDKIHPF & $\beta \mathrm{f}(32-52) 1 \mathrm{P}$ \\
\hline 2555.0647 & 2555.1217 & FQUEKQQQTEDELQDKIHPF & $\beta \mathrm{f}(33-52) 1 \mathrm{P}$ \\
\hline 2983.2816 & 2983.2873 & FQUEEQQQTEDELQDKIHPFAQTQ & $\beta \mathrm{f}(33-56) 1 \mathrm{P}$ \\
\hline
\end{tabular}


Table I. Continued.

\begin{tabular}{lclc}
\hline $\begin{array}{l}\text { Observed } \\
\text { mass }\end{array}$ & $\begin{array}{c}\text { Calculated } \\
\text { mass }\end{array}$ & \multicolumn{1}{c}{ Sequence } & $\begin{array}{c}\text { Sequence assignment } \\
\text { of the peptide }\end{array}$ \\
\hline $\begin{array}{l}\text { Fraction } I V \\
1793.8834\end{array}$ & 1793.8964 & KYKVPQLEIVPNUAE & $\alpha_{\mathrm{S} 1} \mathrm{f}(103-117) 1 \mathrm{P}$ \\
1247.627 & 1247.6163 & SU*EVFTKKTK & $\alpha_{\mathrm{S} 2} \mathrm{f}(143-152) 1 \mathrm{P}$ \\
1509.5979 & 1509.6113 & SUUEESITRINK & $\beta \mathrm{f}(17-28) 2 \mathrm{P}$ \\
3053.4078 & 3053.4019 & KIEKFQUEEQQQTEDELQDKIHPF & $\beta \mathrm{f}(29-52) 1 \mathrm{P}$ \\
3481.5900 & 3481.6038 & KIEKFQUEEQQQTEDELQDKIHPFAQTQ & $\beta \mathrm{f}(29-55) 1 \mathrm{P}$ \\
2559.1105 & 2559.1741 & KIEKFQUEKQQQTEDELQDK & $\beta \mathrm{f}(29-48) 1 \mathrm{P}$ \\
Fraction V & & & $\beta \mathrm{f}(14-27) 3 \mathrm{P}$ \\
1790.6248 & 1790.6413 & ESLUUUEESITRIN & $\beta \mathrm{f}(15-25) 3 \mathrm{P}$ \\
1434.4467 & 1434.4718 & SLUUUEESITR & $\beta \mathrm{f}(15-27) 3 \mathrm{P}$ \\
1661.585 & 1661.5987 & SLUUUEESITRIN & $\beta \mathrm{f}(16-25) 3 \mathrm{P}$ \\
1347.4384 & 1347.4397 & LUUUEESITR & $\beta \mathrm{f}(17-28) 3 \mathrm{P}$ \\
1589.5713 & 1589.5776 & UUUEESITRINK &
\end{tabular}

standard deviation of the AUCs of $215 \mathrm{~nm}$ absorbance of molecules eluted from the IMAC-Fe(III) column by increasing phosphate concentration gradient vs. time was $3.4 \%$, which indicates a good repeatability.

The chromatograms obtained from the fraction of the Beaufort cheese WSEs that bound to the column were then divided into five sections and the corresponding fractions gathered (Fig. 1). In the work of Lund and Ardö [14], fractions I and II-V corresponded to mono-, di- and polyphosphorylated CPPs, respectively.

As long as AUCs of $215 \mathrm{~nm}$ absorbance vs. time are considered, fractions IV and V appear to be more rich in CPPs than fractions I-III, suggesting that most of the extracted CPPs would be polyphosphorylated ones.

\subsection{Identification of Beaufort cheese CPPs}

In order to check whether mainly CPPs were isolated from Beaufort cheese following IMAC, fractions III-V of the cheese WSE were identified using LC-ESI-MS/ MS (Tab. I). A total of 55 different peptides could be identified, including 48 CPPs. Most of the identified CPPs (Tab. I) arose from $\beta$-casein (30 peptides), while 11 and 7 CPPs corresponded to $\alpha_{\mathrm{S} 1}-$ and $\alpha_{\mathrm{S} 2}$-casein fragments, respectively, their molecular weights were calculated and varied from 650 to $3500 \mathrm{~g} \cdot \mathrm{mol}^{-1}$.

Concerning the non-phosphorylated peptides, two from $\alpha_{\mathrm{S} 1 \text {-casein (moreover, these }}$ two fragments contained histidine residues), one from $\alpha_{\mathrm{S} 2}$-casein, one from $\beta$-casein and three from $\beta$-lactoglobulin were identified. The pIs of all these peptides were calculated: either they bear a negative charge at $\mathrm{pH} 7$ or they have a strong negative local charge, which would indeed explain their low affinity for the CEC column and also their elution in the pool with CPPs. However, compared to the total number of identified peptides (55), and considering that LC-ESI-MS/MS data cannot be used to determine the quantity of each identified peptide, we may consider that non-phosphorylated peptides in fractions III-V (7) are quantitatively negligible, and that most of the purified peptides obtained after the IMAC step are CPPs. 




Figure 2. Calibration of Superdex ${ }^{\circledR}$ Peptide PE 7.5/300 GFC column using standard peptides. The elution was carried out with $30 \%$ of $0.1 \%$ TFA in acetonitrile and $70 \%$ of $0.1 \%$ TFA in water, with a flow rate of $0.25 \mathrm{~mL} \cdot \mathrm{min}^{-1}$. Detection was carried out at $215 \mathrm{~nm}$.

Contrary to what was observed by Lund and Ardö [14], fractions III and IV contain a mixture of mono- and di-phosphorylated peptides, while only triphosphorylated peptides were present in fraction V. Only two monophosphorylated peptides were found both in fractions III and IV, suggesting that factors other than the degree of phosphorylation (such as peptides $\mathrm{pHi}$ and local charge effects) are also involved in the affinity of peptides for the IMAC-Fe(III) support under the chromatographic separation conditions used in this study.

Mono- to tri-phosphorylated peptides were identified in the 6-month-old Beaufort sample: the identified peptides cover all phosphorylation sites of $\beta$-casein, while for $\alpha_{\mathrm{S} 1}$-casein, the phosphoserines S46, S48, $\mathrm{S} 64$ and $\mathrm{S} 66$ were not found, and for $\alpha_{\mathrm{S} 2^{-}}$ casein, only $\mathrm{f}(136-152)$ yielded phosphorylated peptides. The $N$-terminal part of the
$\alpha_{\mathrm{S} 2}$-casein sequence, which contains five close phosphorylated residues, did not yield any polyphosphorylated peptide in our sample. Amongst the CPPs identified in this study, some have ever been isolated from other hard-type cheeses. Thus, some purified peptides corresponding to fragments of the sequence $\mathrm{f}(13-28)$ of $\beta$-casein have previously been isolated from Parmiggiani Reggiano [14], Grana Padano [5, 21], Comté [20] and Emmentaler [8]. In addition, the $\mathrm{f}(61-74) 2 \mathrm{P}$ and $\mathrm{f}(67-74) 2 \mathrm{P}$ fragments from $\alpha_{\mathrm{S} 1}$-casein were also found in Grana Padano $[5,21]$. Considering their sequences, CPPs in Beaufort are probably produced throughout caseinolysis along with cheese ripening, namely as a result of the plasmin activity followed by further aminopeptidase and, possibly, carboxypeptidase activities as suggested by Ferranti et al. [5], Gagnaire et al. [8] and Sforza et al. [21] for other hard-type cheeses. 


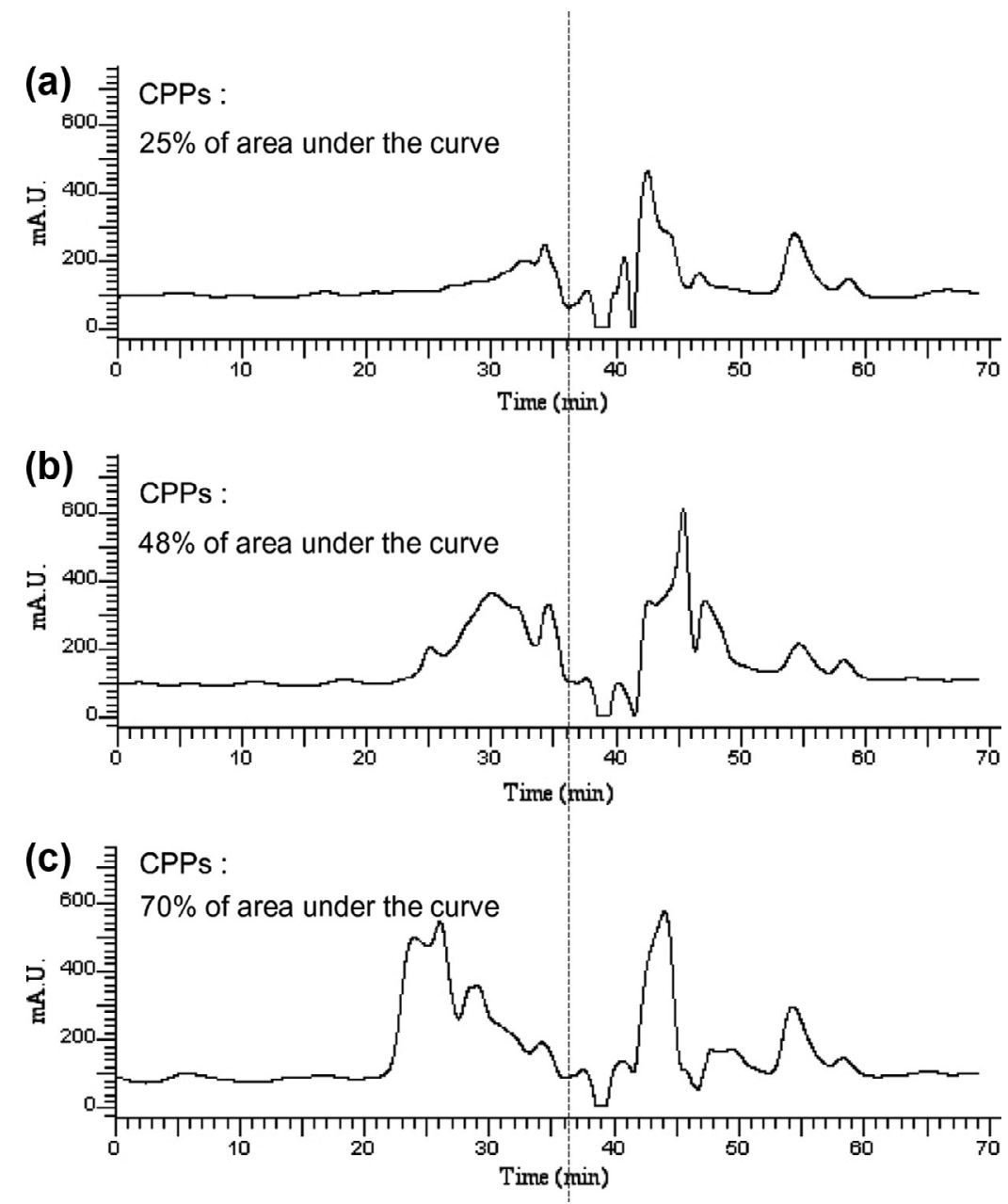

Figure 3. Analysis of IMAC fractions III (a), IV (b) and V (c) obtained on calibrated Superdex ${ }^{\circledR}$ Peptide gel filtration chromatography column. Fractions I and II are not shown because no significant amounts of molecules eluted before $36 \mathrm{~min}$ (i.e. having a molecular weight $>600 \mathrm{~g} \cdot \mathrm{mol}^{-1}$ ) were present. mAU stands for milliunits of absorbance at $215 \mathrm{~nm}$.

More originally, some identified CPPs in Beaufort sample were totally or partially dephosphorylated (Tab. I), thus suggesting the action of phosphatases on phosphocaseins and their fragments during cheese ripening, but further studies are needed in this field [22]. However, the characteristic "acidic motif" Ser(P)-Ser(P)-Ser(P)-Glu-Glu is still carried by all the CPPs found in fraction V, making them potential candidates for having effects on calcium absorption [6].

\subsection{GFC analysis}

A gel filtration chromatography column was calibrated (Fig. 2) in order to get 
a global view of peptide molecular weight distribution in the IMAC fractions. Chromatograms (Fig. 3) were then divided into two main zones: molecules with a molecular weight below $600 \mathrm{~g} \cdot \mathrm{mol}^{-1}$ and molecules between 600 and $10000 \mathrm{~g} \cdot \mathrm{mol}^{-1}$. As the samples were ultrafiltrated on $10000 \mathrm{~g} \cdot \mathrm{mol}^{-1}$ cut-off membranes, molecules with a molecular weight above this value were not yielded. The limit of $600 \mathrm{~g} \cdot \mathrm{mol}^{-1}$ was chosen according to the results of the mass spectrometry analysis performed by Lund and Ardö [14]: the smallest identified peptide presenting a part of the characteristic "acidic motif" Ser(P)Ser(P)-Ser(P)-Glu-Glu was considered a CPP and had a similar molecular weight. The AUCs were calculated for both zones. The results reveal that fractions I and II likely contain phosphoserine (this hypothesis is substantiated by the fact that a phosphoserine standard is eluted with the same retention time - data not shown). Concerning fractions III-V, the proportion of molecules with a molecular mass $<600 \mathrm{~g} \cdot \mathrm{mol}^{-1}$ (like phosphoserine) was $75 \%, 52 \%$ and $30 \%$, respectively. This suggests that phosphoserine is also likely eluted with CPPs and further justifies the necessary GFC step to remove compounds with a molecular mass inferior to $600 \mathrm{~g} \cdot \mathrm{mol}^{-1}$, which are not CPPs. This procedure is a semi-quantitative one if AUCs of $215 \mathrm{~nm}$ absorbance vs. time is considered, since the samples loaded on to the column are mixtures of peptides, and each peptide's individual response at $215 \mathrm{~nm}$ may be strongly varying (according to their individual molecular extinction coefficients). Considering that the $215 \mathrm{~nm}$ molecular extinction coefficients of peptides in pooled IMAC fraction were around $7.52 \times$ $10^{7} \mathrm{~g} \cdot \mathrm{L}^{-1} \cdot \mathrm{cm}^{-1}$, the CPPs content of the Beaufort cheese sample was thus estimated at $1.9 \mathrm{~g} \cdot 100 \mathrm{~g}^{-1}$. Kawahara et al. [12] reported that the overall CPPs concentration in Camembert cheese following its in vitro digestion by trypsin was $2.8 \mathrm{~g} \cdot 100 \mathrm{~g}^{-1}$.
Meisel [18] calculated that, considering only the $\beta-\mathrm{CN}(1-25), \quad \alpha_{\mathrm{S} 1}(43-58)$ and $\alpha_{\mathrm{S} 1}(59-79)$ casein fragments, $44.5 \mathrm{mg}$ of these CPPs could be liberated from $1 \mathrm{~g}$ of milk proteins. In the present case, an overall $1.9 \mathrm{~g} \mathrm{CPPs} \cdot 100 \mathrm{~g}^{-1}$ of the analysed Beaufort cheese concentration corresponds to a $73 \mathrm{mg} \mathrm{CPPs} \cdot \mathrm{g}^{-1}$ of protein concentration.

\section{CONCLUSION}

We here tested a modified method to purify and quantify CPPs from Beaufort cheese. The quantity of CPPs in the Beaufort cheese sample analysed was estimated to be $1.9 \mathrm{~g} \cdot 100 \mathrm{~g}^{-1}$. Our results show that it is efficient to retrieve CPPs, but the degrees of phosphorylation of the peptides retrieved in the different fractions did not completely match with the observations of Lund and Ardö [14], suggesting that other factors are involved in the affinity with the column. Moreover, the method could be simplified by adding an ultrafiltration step onto a 500 Da cut-off membrane to remove phosphoserine and other small molecular mass compounds that are eluted with CPPs instead of the gel filtration chromatographic step.

Acknowledgements: The authors would like to thank Région Rhône-Alpes, Conseil Général de l'Ain and Communauté d'Agglomération de Bourg-en-Bresse for their financial support, and Clémence Desmaris, Sandrine Gouin, Séverine Lafaury and Roselyne Roux for their precious technical contribution.

\section{REFERENCES}

[1] Adamson N.J., Reynolds E.C., Characterization of multiply phosphorylated peptides selectively precipitated from a pancreatic casein digest, J. Dairy Sci. 78 (1995) 2653-2659. 
[2] Addeo F., Chianese L., Sacchi R., Spagna Musso S., Ferranti P., Malorni A., Characterization of the oligopeptides of ParmigianoReggiano cheese soluble in $120 \mathrm{~g}$ trichloroacetic acid/L, J. Dairy Res. 61 (1994) 365-374.

[3] Aimutis W.R., Bioactive properties of milk proteins with particular focus on anticariogenesis, J. Nutr. 134 (2004) 989-995.

[4] Chabance B., Marteau P., Rambaud J.C., Migliore-Samour D., Boynard M., Perrotin P., Guillet R., Jolles P., Fiat A.M., Casein peptide release and passage to the blood in humans during digestion of milk or yogurt, Biochimie 80 (1998) 155-165.

[5] Ferranti P., Barone F., Chianese L., Addeo F., Scaloni A., Pellegrino L., Resmini P., Phosphopeptides from Grana Padano cheese: nature, origin and changes during ripening, J. Dairy Res. 64 (1997) 601-615.

[6] Ferraretto A., Gravaghi C., Fiorilli A., Tettamanti G., Casein-derived bioactive phosphopeptides: role of phosphorylation and primary structure in promoting calcium uptake by HT-29 tumor cells, FEBS Lett. 551 (2003) 92-98.

[7] FitzGerald R.J., Potential uses of caseinophosphopeptides, Int. Dairy J. 8 (1998) 451457.

[8] Gagnaire V., Mollé D., Herrouin M., Léonil J., Peptides identified during cheese ripening: origin and proteolytic systems involved, J. Agric. Food Chem. 49 (2001) 4402-4413.

[9] García M.C., Hogenboom A.C., Zappey H., Irth H., Effect of the mobile phase composition on the separation and detection of intact proteins by reversed-phase liquid chromatography-electrospray mass spectrometry, J. Chromatogr. 957 (2002) 187-199.

[10] Hartmann R., Meisel H., Food-derived peptides with biological activity: from research to food applications, Curr. Opin. Biotechnol. 18 (2007) 163-169.

[11] Hynek R., Kozak A., Drab V., Sajdok J., Kas J., Characterization of casein phosphopeptides in cheese extracts using a combination of immobilized metal chelate affinity and reversed-phase high-performance liquid chromatography, Adv. Food Sci. 21 (1999) 192-196.

[12] Kawahara T., Aruga K., Otani H., Characterization of casein phosphopeptides from fermented milk products, J. Nutr. Sci. Vitaminol. 51 (2005) 377-381.
[13] Kuchroo C.N., Fox P., Soluble nitrogen in cheddar cheese: comparison of extraction procedures, Milchwissenschaft 37 (1982) 331-335.

[14] Lund M., Ardö Y., Purification and identification of water-soluble phosphopeptides from cheese using $\mathrm{Fe}(\mathrm{III})$ affinity chromatography and mass spectrometry, J. Agric. Food Chem. 52 (2004) 6616-6622.

[15] Meisel H., Overview on milk proteinderivated peptides, Int. Dairy J. 8 (1998) 363-373.

[16] Miquel E., Gomez J.A., Alegra A., Barber R., Farr R., Recio I., Identification of casein phosphopeptides released after simulated digestion of milk-based infant formulas, J. Agric. Food Chem. 53 (2005) 3426-3433.

[17] Morgan M.V., Adams G.G., Bailey D.L., Tsao C.E., Fischman S.L., Reynolds E.C., The anticariogenic effect of sugar-free gum containing CPP-ACP nanocomplexes on approximal caries determined using digital bitewing radiography, Caries Res. 42 (2008) 171-184

[18] Peres J.M., Bouhallab S., Bureau F., Neuville D., Maubois J.L., Devroede G., Arhan P., Bougle D., Mechanisms of absorption of caseinophosphopeptide bound iron, J. Nutr. Biochem. 10 (1999) 215-222.

[19] Reynolds E.C., Riley P.F., Adamson N.J., A selective precipitation purification procedure for multiple phosphoseryl-containing peptides and methods for their identification, Anal. Biochem. 217 (1994) 277-284.

[20] Roudot-Algaron F., Le Bars D., Kerhoas L., Einhorn J., Gripon J.C., Phosphopeptides from Comté cheese: nature and origin, J. Food Sci. 59 (1994) 544-547.

[21] Sforza S., Ferroni L., Galaverna G., Dossena A., Marchelli R., Extraction, semi-quantification, and fast on-line identification of oligopeptides in Grana Padano cheese by HPLC-MS, J. Agric. Food Chem. 51 (2003) 2130-2135.

[22] Shakeel-Ur-Rehman, Farkye N., Yim B., A preliminary study on the role of alkaline phosphatase in cheese ripening, Int. Dairy J. 16 (2006) 697-700.

[23] Tsuchita H., Goto T., Shimizu T., Yonehara Y., Kuwata T., Dietary casein phosphopeptides prevent bone loss in aged ovariectomized rats, J. Nutr. 126 (1996) 86-93. 